\title{
Social Media Facebook in Rural Communities (Case Study of Bandar Klippa Village Community against Changes in Communication Psychology)
}

\author{
Akbar Aldi Kautsar ${ }^{1}$, Mailin², Ade Soraya ${ }^{3}$, Mas Khairani ${ }^{4}$ \\ ${ }_{1,2,3,4}$ Faculty of Dakwah and Communication, Universitas Islam Negeri Sumatera Utara, Indonesia
}

\begin{abstract}
This research is entitled "Facebook Social Media in Rural Communities (case study of Bandar Klippa Village Community against Changes in Communication Psychology)". This study aims to determine the psychological effect of rural community communication on social media Facebook and to find out what are the research criteria for rural communities in choosing social media. The time of the research was carried out from December 2, 2021 - December 10, 2021. The theories that support this research include: Media, Social Media, Facebook, and Village Community. This study uses a qualitative research method (Case Study). The population in this study is the Bandar Klippa Village Community.
\end{abstract}

\section{Keywords} media; social media; society

\section{Introduction}

The community is very thick with the greeting process between people who meet face to face. This greeting process is used to the process of interaction that develops in this place. The interactions that occur show a harmonious relationship that exists in this society. This harmony provides a positive value for all individuals, including immigrants who carry out their activities in the area.

With the increasingly rapid development of the era in the field of technology, one's life is not young regardless of the name of the media, especially social media. Both people who live in urban areas and those who live in rural areas. Always important to each other's life. Even though technological developments such as computers, cellphones and developments in social media itself are certainly very taking care of themselves by the people who use it

Call it social media that is growing rapidly every era, such as Instagram, Facebook, Line, WhatsApp, of course, each social media platform offered to the public now depends on each individual. Because each of the social media platforms offered, each has its own advantages and disadvantages.

Of course, every urban community tends to use social media such as line, or even Instagram, but it is different from people who live in rural areas who tend to choose Facebook social media. Although all social media can be accessed or used by each individual. Of course there is a special love for social media itself, both from the simplicity of social media offered by social media, so that users who will use the social media platform easily learn and don't feel confused.

When you have played on other social media platforms or social media such as Facebook, of course you can have an addiction opportunity in terms of playing social media, of course when playing social media it has a dose, it doesn't happen. The name i 
addiction in terms of social media, but when someone is addicted to social media then will be difficult to change so as not to become addicted. For example, in the past, women who did not know the name of technology, especially social media such as Facebook, of course, had every job done. It's a different story in the current era where women playing social media make them feel dependent and addicted.

Things like this, of course, both parents and children are slowly changing in their psychological point of view. Is it because you often play social media, you can get angry, nervous or something else. Of course, if this is allowed and without a wall to fortify oneself, one can have addictions and dependencies that are difficult to change. Therefore, the authors are interested in researching how the psychological effects of rural communities on social media Facebook, then what are the criteria for rural communities in terms of choosing social media.

\section{Review of Literature}

\subsection{Media}

Media is as of communication channels. Etymologically, the term media comes from Latin which is the plural form of the word medium. Literally, media means an intermediary, namely an intermediary between the message source and receiving the message (a receiver). Some things that are included in the media are films, television, diagrams, printed media (printed material), computers, and so on.

Another notion of media comes from McLuhan. He called media is the message (the medium is the message). This interpretation is intended to describe media issues that are more important than the message presented by the media itself. For more details, Luhan explained that the media that became a communication channel had the power to influence the user community. One example is the media facebook. It's not the content of the messages on social media that matters the most. More than that, its users feel that the most important thing is that they use Facebook itself.

\subsection{Social Media}

\section{a. Definition of Social Media}

Definition of social media in explained by Van Dijk. Social media is a media platform that focuses on the existence of users that facilitates them in their activities and collaboration. Therefore, social media can be seen as an online facilitator that strengthens the relationship between users as well as a social bond. Social media is an example of a relatively recent development of information technology (Marbun et al, 2020).

\section{b. Social Media Functions}

Social media has several functions as follows:

1. Social media is media designed to expand human social interaction using the internet and web technologies.

2. Social media has succeeded in transforming the practice of unidirectional communication with broadcast media from one media institution to many audiences ("one to many") into the practice of dialogical communication betweenmany audienc ("many to many")

3. Social media supports the democratization of knowledge and information. Transforming humans from the user of the message content to the maker of the message itself. 
In addition, there is another opinion according to Puntoadi, namely that social media users function as follows:

1. The advantage of building personal branding through social media is that you don't know tricks or pseudo popularity, because it's the audience that decides. Various social media have become a medium for people to communicate, discuss and even give popularity on social media

2. Social media provides an opportunity that serves to interact more closely with consumers. Social media offers a more individualized communication content. Through social media, various marketers can find out the habits of their consumers and carry out a personal interaction, and can build a deep interest.

\subsection{Facebook}

\section{a. Understanding Facebook}

While the notion of Facebook itself is one of the Online Social Networking or social networking sites created to provide technological facilities with the intention that users can socialize or interact in cyberspace.

\section{b. History of the Founding of Facebook}

In the beginning, Facebook was used as a communication tool at Harvard University, but along with the rapid advancement of technology, Facebook grew rapidly throughout the world and even to Indonesia. At first Facebook was called The Facebook and started as a hobby website created by a Harvard University student whose name is Mark Zuckerberg.

February 4, 2004 is a historic date for Facebook, because right on that date Facebook was launched by its creator, Mark Zuckerberg, as a place for Harvard University students to get to know each other. After launching this amazing social networking site in just 24 hours, 1,200 Harvard students are already members. In just 2 weeks, more than half of Harvard students have registered and have an account on Facebook. Even several other campuses around Harvard also joined the facebook network. Within 4 months after launching, 30 campuses have entered the Facebook network.

\section{c. Facebook Impact}

We need to know that Facebook has several impacts, both positive and negative impacts. Starting from the positive impact Facebook has several benefits including:

1. Facebook can make us meet again with relatives, colleagues, and friends who have not seen each other for a long time, even though only in cyberspace, so that we can strengthen the friendship.

2. Facebook makes communication between relatives, friends, and friends easy even if they are far apart. For example, for those who are far from their home area because of assignments, for example, while working or studying outside the city or abroad, using Facebook will feel close and friendship can continue to be established.

3. With Facebook we can exchange ideas very easily. Information exchange is very well facilitated. For example, when we need something or want to know about something, we just write it in the status, there will be many responses from our friends.

4. With groups and fan pages, we can also find the information we need, by looking for the group we want and then we write it on the group wall, friends in the group will provide the information we need. .

5. Facebook can also be useful as a learning medium, where students can discuss lessons at school via Facebook, or students can also discuss with their friends via Facebook, even educators can provide learning materials through Facebook. 
In addition to having a positive impact, Facebook also turns out to have a negative impact, because Facebook is a communication tool and that tool is neutral depending on how users use it. Here are the negative impacts of Facebook:

1. Addicted

Many company employees, lecturers, students and students play Facebook until they become addicted, until they forget the time they are active, it can actually be reduced if they are smart to manage their time well when using Facebook.

2. Replacement of social life

Facebook is very easy to use, so young some people feel enough to interact via Facebook, thereby reducing the frequency of meeting face to face. There's something about this kind of interaction. Meeting face to face is very different and should not be replaced by meeting in cyberspace. Chats, stares, facial expressions, jokes via Facebook cannot be replaced by a series of words and even videos.

3. Hostility

In Facebook we are free to write anything, often without realizing it we write things that should not be conveyed to the social sphere. Personal problems should not be written on Facebook because it will cause a negative response for those who see it. Moreover, writing insulting words, making fun of each other's friends on Facebook. From there will be hostility.

4. Forbidden sites

Nowadays, there are a lot of prohibited sites that are not suitable for minors to access. Actually this site is made for adults who experience sexual disorders, but what can you do, the internet world knows no age, anyone can access it. Alhamdulillah, now the Indonesian government has blocked these banned sites.

5. Fraud

Fraud after all is a crime, because it harms other people, regardless of the media they use. Likewise, fraud is currently rife through Facebook. The fraudsters usually use fake profiles to carry out their actions, usually the information shared on their profiles is not very goodmany. The photo used is also displayed with an innocent face (innocent face like innocence), so that no one will suspect.

For example, the fraudster is a beautiful girl, while the victim is a young person, for example the fraud case committed by Selly Yustiawan alias Rasellya Rahman Taher. Before committing fraud through Facebook, this beautiful woman was known as a master conman since 2007.

The victims are not one or two people, but have sweat and have committed fraud estimated at tens of millions of rupiah. With a beautiful face and the ability to talk, he managed to deceive many people and was willing to give up his money. The motives for this fraud are various, ranging from the credit business, being helped to find work, borrowing money and much more.

\subsection{Villagers}

Soerjono Soekanto, the term community can be translated as the local community. The local community is an area of social life marked by a certain degree of social relations. The basic basis of the local community is the locality and the feelings of the local community

According to Abdul Syani in Basrowi mentions that society is characterized by four characteristics, namely the existence of interaction, a bond of typical behavior patterns in all aspects of life that are steady and continuous, and a sense of identity to the group, where the individual concerned becomes a member of the group. 


\subsection{Communication Psychology}

Communication psychology according to Jalaluddin Rahmat is defined as "Psychology is the science that attempts to describe, predict, and control mental and behavioral events" (science that seeks to describe, predict and control mental and behavioral events in communication. Meanwhile, events mental is what Fisher called (internal mediation of stimuli), as a result of ongoing communication Behavioral events are what appear when people communicate

Benefits of studying the psychology of communication Effective communication according to Stewart L. Tubbs and Sylvia Moss raises five things:

a. Definition

Understanding means careful acceptance of the contents of the stimuli as intended by the communicator.

b. Enjoyment

This communication is called phatic communication, it is intended to cause pleasure.

This communication can be warm, intimate, and fun.

c. Affect Attitude

Persuasive communication requires an understanding of the factors in yourself communicate. Persuasion is defined as "the process of influencing people's opinions, attitudes, and actions by using psychological manipulation so that the person acts as he wishes"

d. Good Social Relations

e. Action

Meaning that it can influence actions so that it gives rise to understanding of the delivery of communication

\section{Research Methods}

\subsection{Data Types and Sources}

\section{a. Types of Research}

This research uses a case study approach which intends to describe the results of the study and seeks to find a comprehensive picture of a situation. The choice of this methodology is because the phenomenon to be studied is a case that requires an in-depth descriptive study.

According to Robert K. Yin, the case study is one of the research methods in the social sciences. In general, this method is a more suitable strategy if the main question of a research relates to the how and why questions. In addition, case study research can be divided into three types, namely explanatory, exploratory and descriptive case studies. Meanwhile, in this study, the researchers focused more on the descriptive approach.

\section{b. Data Source}

1. Primary Data

Primary Data is a data source that directly provides data to data collectors. In this writing, the data obtained were observed directly. Which is obtained from the results of interviews between the authors and research subjects in this study.

\section{Secondary Data}

The definition of secondary data according to Sugiyono is a source that does not directly provide data to data collectors, for example through other people or documents. 
This data was obtained indirectly through the media, and other information related to the use of Facebook by the people of the village of Bandar klippa.

\subsection{Determination of Informants}

The informants of this research include three kinds, namely:

a. Key informants (key informants), namely those who know and have various basic information needed in research. In this case, women in the village of Bandar Klippa.

b. The main informants, namely those who are directly involved in the social interactions studied. The main informant in this study was the Men of the community in Bandar Klippa Village

c. Additional informants, namely those who can provide information even though they are not directly involved in the social interactions studied.

\subsection{Data Collection Technique}

The data collection technique carried out by this researcher uses data collection techniques with structured and document interviews, where the researcher uses structured interview techniques so that interviews with informants feel easy because the questions made by researchers will be asked to the informants in a systematic and structured manner. also later researchers will look at the track record of the use of social media such as facebook against women in the village of Bandar klippa. How far has the effect of social media Facebook on the psychology of communication?

\subsection{Data Validity Check Technique}

There are several techniques that can be used to determine the validity of the data, namely:

a. Triangulation techniques between data sources, data collection techniques, and data collection in which in this last case the researcher will try to get colleagues or assistants in extracting data from residents in locations who are able to help after being given an explanation.

b. Checking the truth of information to informants that have been written by researchers in research reports (member check).

c. Will discuss and make seminars with the theme of peers in the study area (peer debricfing), including corrections under the supervisors. d. Extension of research time. This method will be used not only to obtain more complete evidence but also to check the consistency of the actions of the informants.

\subsection{Data Analysis Technique}

Domain analysis is used to analyze the general description of the research object or the surface level, but is relatively intact about the research object. Domain analysis techniques are usually used in exploratory research. This means that the results of this study are only targeted at obtaining a complete picture of the object under study, without having to specify in detail the elements that exist in the integrity of the research object. 


\section{Results and Discussion}

\subsection{Description of Research Results}

a. Psychological Effects of Community Communication in Rural Areas on Facebook Social Media

Based on the research that the author conducted on informants, namely community members in Bandar Klippa Village, in general the perceived psychological effect of communication is the men or their husbands.

Based on the informants who were researched, the husbands judged that if there was a change in his wife, the effects that arise, occur and are felt when the husband asks to cook or get him a drink, but his wife is slow and not alert to what her husband ordered.

Because when the husband told his wife, his wife still had time and focused on the cellphone where his wife was busy playing social media such as Facebook.

Then there was a communication barrier between husband and wife in communicating. This is very different when the wife has not known a social media like Facebook. Because when you don't know a social media like Facebook, when the husband tells his wife something is faster, there is no objection and gentle

But now it becomes a problem when his wife knows a social media like Facebook tends to be less gentle in communicating with her husband so that there can be a change in a psychology between her husband or wife in terms of communicating. Because it has a difference when before and after knowing a social media like Facebook, where in the past, his wife tended to focus more on activities in her household.

But it all slowly shifted when the wife was familiar with social media such as Facebook, now household activities can be said to not be the focus. Because now women or their wives prefer to do homework before uploading social media number one. For example, women who are supposed to cook for their households or for their husbands and wives with the focus now more on preparing the ingredients for cooking, before being fried or cooked, they must be uploaded first to social media such as Facebook with the status "cook first for this" husband and children"

Specifically, based on the informants who were researched, the husbands judged that his wife did not have a very drastic change or there was a change in his wife. Because her husband thinks that his wife is good at dividing time between work at home and rest time which is used to play a social media like Facebook.

Seen when still with the same habit the wife remains obedient, alert and focused when her husband orders homework activities, so when his wife is not familiar with social media such as Facebook her husband judges that the wife pursues a homework with focus, gentle and alert

When after getting to know social media such as Facebook. Yes, his wife is still there. There is no change in his wife that can have a psychological effect on communication between husband and wife. So that in their household there is no communication barrier between husband and wife both in terms of psychology between husbands, both psychology between wives or communication between husband and wife.

\section{b. What are the Criteria for Rural Communities in Choosing Social Media?}

Based on the research that the author conducted on informants, namely community members in Bandar Klippa Village, in general the people in Bandar Klippa Village that those who use social media more and frequently use social media tend to be women, where women in Bandar Klippa Village choose the criteria in using social media tends to social media which is easy to learn and has many features. 
Based on the informants interviewed that women prefer social media platforms such as Facebook. Because in the Facebook social media there are many features, such as: on Facebook you can upload an updated status, you can also upload a status that contains photos.

On the other hand, there is a comment and like column, where this comment can think they feel popular, and where this like has many unique icon emoticons which can make women happy and free to choose to use icon emoticons in liking a post on social media such as Facebook.

Like other things in social media such as Facebook, you can send messages between long distances where you get to know each other or create friendships with old friends or new friends, where in sending messages on Facebook you can also send photos, videos or emoticons.

The thing that is no less important is that on social media such as Facebook there is a group, where users can include old friends or new friends in the group. The most important thing in the community in Bandar Klippa Village is because the appearance on the Facebook page is not complicated with other social media, such as line or Instagram, so that there is a simple display that makes people simple and easy to adapt to learn or use social media like Facebook itself.

On the one hand, the Facebook feature, which has a live feature, is currently in season, where on social media such as Facebook, it often goes live, where the live contains sales, whether selling clothes, selling pants, shoes or other sales. Which is where the women in Bandar Klippa Village often spend their time on social media such as Facebook.

In particular, women in Bandar Klippa Village actually prefer social media criteria such as Instagram. Because based on the informants studied, it seems that their lifestyle and sociality can be displayed everywhere on social media such as Instagram. Because they feel that social media like Instagram is more suitable to show off their activities like he just went to a beautiful place with fashionable clothes and showed it to followers on his Instagram, or what could be said follows on his personal Instagram account.

Although social media such as Instagram is somewhat complicated among the women in Bandar Klippa Village. The reason that can be ascertained and strong because they prefer to choose to upload a video or photo on Instagram. Because they think that uploading photos and videos can be one of them as a relic when the storage memory is damaged or the cellphone is damaged, there are mementos left in the Instagram post.

\subsection{Discussion}

The theory used is the theory of communication psychology which in more detail uses a psychoanalytic theory initiated by Sigmund Freud, humans are controlled by the desires that are hidden within them. Human behavior is the result of the interaction of three

Where people who live in Bandar Klippa Village who tend to use social media such as Facebook are women or wives, of course, in this case, women in Bandar Klippa Village are certainly controlled by hidden desires.

One of the hidden desires of women who live in Bandar Klippa Village is to exist in playing social media such as Facebook. So with control in him, he is about to exist to play social media such as Facebook.

Of course, in this case the level of interaction in the human personality (women) who live in Bandar Klippa Village has an id, ego or super ego. This is clearly based on the results of interviews with informants in the field of the level of ego that is owned by women who live in Bandar Kliipa Village. 
There are times when her husband tells her to do some homework but the mother is not quick to do it, even less gentle to respond to her husband's orders, and before doing some homework, try to upload a status, photo or video on social media such as Facebook. which is where to manifest his personality in playing social media such as Facebook.

Because having a hidden desire is an existence in playing social media such as Facebook owned by women who live in Bandar Kliipa Village, of course the creation of an id, ego or super ego in the person which causes a psychological effect and communication between husband and wife.

So in that case, communication between husband and wife tends to have obstacles between the two. Which is where the husband wants his wife to be obedient and alert when her husband asks for homework but the wife is looking addicted to playing social media such as Facebook.

Because in human behavior which results from interactions in personalities such as the id, ego, super ego, it cannot be separated in everyday life. For example, in the case of id which is the human personality (women) who live in Bandar Klippa Village which stores biological impulses, instinct centers that move based on the pleasure principle,

The principle of fun in this case is to exist to upload a status, photo or video selfish, immoral and ignorant. Other users on social media such as Facebook who are friends with themselves whether they like it or not with what they upload, the most important thing is a personal desire in pleasure to exist to show their identity either from photo or video status conveyed through updated uploads.

There are 10 people (women) who live in Bandar Klippa Village who are the author's informants from nine kelurahan. These 10 people include people (women) who tend to be active in Facebook social media users. So in this case the research discusses the results of interviews conducted with them which is related to the title of the research above. In terms of research, not only from the women's side, but here we also see how the response of a husband who often sees or is next to a wife who often plays social media facebook.

From the first informant, he explained the answers to several questions given to him, with the answer that the social media that is often used for women is Facebook, because Facebook is a type of social media that is very easy to use among their age. Because in playing Facebook, which is done by the mother, it has been a long time and to carry out daily activities there must always be someone whose name is they are active or online on this Facebook social media. As for the informants' responses to questions about the husband's response to the mother when asked even though the mother was playing Facebook, they only answered that her husband had gotten used to it. But he explained that at the beginning I used Facebook, their husbands objected, but over time it has become a habit. And the next question posed to the mother was about the impact that the mother often used on social media on the psychology of their communication in the household. The mother replied that there must be, but only at the beginning. Because this has become commonplace. Therefore, at least we remind each other about the good things in the household that we have. Turning away on Facebook, especially in the association of women, is only done for their entertainment. Like just venting our fun and daily activities. No more than that.

Apart from the community (women), husbands are also informants in this study. In this case, the husbands of the wives who use Facebook social media also received several questions that represented them as husbands whose wives were active in the use of Facebook's social media. The questions asked are based on matters relating to the title of the study. 
The questions posed to the informants for the husbands were posed to the husbands of the female informants who were first interviewed. In this case, the question posed by the husband is about the psychological effect of wife-husband communication on the tendency to play social media, in this case the first informant who is the husband of a mother who is active in playing facebook. The man replied that the effect must be there, because things that were not done before were done, it is also the same as how a wife is now sharing everything with everyone through her Facebook, so I don't like it like that. Especially now at home more focused on his facebook, So yes, I am now a bit firm in the sense of being able to direct something which should be prioritized, like that I conveyed to my wife so that there would be no communication that would not blame each other. When it comes to the changes that have happened to my wife after using Facebook, this is mostly in terms of what we usually eat and eat right now, whatever we want to do, we have to take a photo so we can post it. This is probably what made the change. In terms of communication barriers that have occurred until now, how about we, especially myself as the head of the household, must be able to guide and build so that unwanted things happen. So if there are no communication barriers, it's still as usual. As for the next question given to the resource person regarding the wife's response when the husband ordered something activity, his response was the response from the wife if for now it is because always or wherever she is holding a cellphone, so the process that is ordered to the wife goes through the process of stopping the previous cellphone toy for a moment use it, but still within a reasonable time the wife's response when something is ordered and there is nothing that causes other things such as making me angry and things that make me uncomfortable. But it's all still in a normal way, that's all about new and unusual things, which is often uploading new events or things. The next question regarding his wife's daily use of social media, he replied that with the daily use of social media, there must have been a lack of communication earlier, but I try to continue to give the best for the family, just giving advice to each other so that things don't happen to each other between husband and wife. Such was the answer from the first informant from the husband whose wife often uses Facebook.

As for the answers that were submitted from the other nine sources, almost all of the answers given were the same and the related discussions were not much different from the wife's resource persons who often used Facebook social media every day. Therefore, the researcher only included one evidence of interviews conducted with representatives of the first informants to be placed in this discussion section. Which is their answer in the selection of social media all choose which facebook is used, as well as with this facebook which they often play, although it can be said they are almost addicted to continuing to play facebook but they also do not forget that they are a wife who has to take care of the activities in at home like taking care of children and husband.

As well as for nine informants from the husband whose wife often uses social media Facebook, I also limit only one informant to be included in the research paper because almost all of the answers related to what they want to convey. Almost all of them said that for their wives they used Facebook to keep the household intact, so from them the head of the family must be firm in their daily lives so that unwanted things don't happen and take care of each other, even though at the beginning they were a little disturbed by their wife's activities but now they are used to the things they do with their wives every day. 


\section{Conclusion}

The use of social media such as the Facebook platform tends to have the opportunity to risk addiction or dependence when playing, both parents and children cannot escape the effects if they exceed the limit on playing social media who are afraid that later it will be at risk or have an impact on the psychology of the person or the effects on the psychology of communication caused by that person.

So whatever it is social media, only the individual can fortify himself or how much he uses social media in a day, with self-control regarding social media users can prevent us from a change in the psychology of communication that exists within the individual.

From the results of these studies that in carrying out social media playing activities, especially Facebook, we as wives must be able to balance how we can run good communication with families, especially to husbands and children who are at home by being able to share time and as wives many say that this Facebook also as entertainment and can be said as a place to pour out their hearts. And they also say that in playing Facebook they can add friends, but must also maintain their family relationships and not forget the affairs in their household.

In the results of the study, the husband whose wife often plays Facebook they also don't mind but at the beginning there may be a feeling of discomfort with each other, because this has become a common thing then those who are the head of the family must be able to put their position and how they can guide their wives for better things disturbed or not they are now trying to understand what their wives are doing. As long as what is done is beyond reasonable limits, what should not be done.

That it can be concluded from the results of this study, that women in Bandar Klippa Village experienced changes only in parts that they usually don't do, such as something new that now needs to be posted and a complaint made on Facebook. But if the influence in household matters does not have a big effect in the sense that things do not happen that make affairs in going out or obligations as a wife and mother in the house do not disappear and the communication that occurs also occurs and is still in a form that is in accordance with the household as usual.

\section{References}

Ahmad Saebani, Beni. 2012. Pengantar Antropologi .Bandung: CV Pustaka Setia Basrowi. 2005. Pengantar Sosiologi. Yogyakarta: Insan Cendekia

Hamidi. 2004. Metode Penelitian Kualitatif: Aplikasi Praktis Pembuatan Proposal dan Laporan Penelitian. Malang: UMM Press

Indriana, Dian. 2011. Ragam Alat Bantu Pengajaran. Cet pertama. Jogjakarta: DIVA Press Kurniali, Sartika. 2009. Step by Step Facebook. Jakarta: PT. Elek Media Komputindo Madcoms, Andi. 2009. Gaul Berteman Lewat Facebook. Yogyakarta: C.V Andi Offiset Laksana, Muhibudin Wijaya. 2015. Psikologi Komunikasi Membangun Komunikasi yang Efektif dalam Interaksi Manusia. Bandung: Pustaka Setia

Marbun, D. S., et al. (2020). The Effect of Social Media Culture and Knowledge Transfer on Performance. Budapest International Research and Critics Institute-Journal (BIRCI-Journal), Volume 3, No 3, Page: 2513-2520.

Morissan. 2013. Teori Komunikasi Individu hingga Massa. Jakarta: Kencana Prenada Media Group

Nasrullah, Rulli. 2017. Media Sosial: Perspektif Komunikasi, Budaya, dan Sosioteknologi. Bandung: Remaja Rosdakarya 
-----, 2018. Khalayak Media Identitas, Ideologi, dan Perilaku pada Era Digital. Bandung: Simbiosa Rekatama Media

Ninja Team. 2009. Facebook Untuk Semua Orang, Untuk Semua Urusan. Jakarta: PT Jasakom

Puntoadi, Danis, 2011. Menciptakan Penjualan Melalui Social Media. PT Elex Komputindo: Jakarta

Rakhmat, Jalaludin. 2007. Psikologi komunikasi. Bandung: Remaja Rosdakarya

Riswandi. 2013. Psikologi Komunikasi. Yogyakarta: Graha Ilmu

Robert K. Yin. 2006. Studi Kasus dan Metode. Penerjemah M. Djauzi Muzakir. Jakarta: Raja Garafindo Persada

Sanjaya, Ridwan. 2009. Panduan Cepat Menguasai Facebook. Jakarta: PT. Elek Media Komputindo

Soerjono Soekanto. 1982. Pengantar Penelitian Hukum. Jakarta: Universitas Indonesia Press

Soerjono Soekanto. 2006. Sosiologi Suatu Pengantar. Jakarta: Raja Grapindo Persada

Sugiyono. 2016. Metode Penelitian Kuantitatif, Kualitatif dan R\&D. Bandung: PT Alfabet

Suyanto, Bagong. 2005. Metode Penelitian Sosial: Bergabai Alternatif Pendekatan. Jakarta: Prenada Media

Uma Sekaran, 2006. Metode Penelitiaan Bisnis. Jakarta: Salemba Empat

https://docplayer.info/72561650-Psikologi-komunikasi.html

http://prezi.com/vddmcub_-ss_/social-media-definisi-fungsi-karakteristik/ 